\title{
Dikdörtgen Temel Altında Gerilme ve Taşıma Gücü Analizi
}

\author{
Yakup TÜREDİ ${ }^{* 1}$, Murat ÖRNEK ${ }^{1}$ \\ ${ }^{1}$ İskenderun Teknik Üniversitesi, İnşaat Fakültesi, İşaat Mühendisliği Bölümü, Hatay \\ Geliş tarihi: 25.06.2015 Kabul tarihi:25.12.2015
}

\section{Özet}

Bu çalışmada, dikdörtgen kesitli model temelin farklı yükleme koşullarında zemine oturması sonucunda meydana gelen düşey gerilme ve taşıma gücü değişimleri deneysel ve teorik olarak araştırılmıştır. Merkez ve eksantrik yüklemeler altında ilave düşey gerilme artışları derinlik boyunca yatayda yerleştirilen gerilme ölçer vasıtasıyla laboratuvar ortamında model deneyler yapılarak ölçülmüştür. Ayrıca yük-oturma değerleri de yük hücresi ve deplasman ölçerler vasıtasıyla elde edilmiştir. Daha sonra deney sonuçları, literatürde mevcut teorik yöntemlerle (Boussinesq, Westergaard ve 2:1 Yöntemi) karşıslaştırılmıştır. Deneylerde gevşek kum zemin kullanılmıştır. Deneyler, İskenderun Teknik Üniversitesi İnşaat Mühendisliği Bölümü Geoteknik Laboratuvarı'nda yapılmıştır. Deney sonuçları, eksantrisite arttıkça taşıma gücü değerlerinin azaldığını göstermiştir. Aynı zamanda merkezden uzaklaşıldıkça da gerilme değerlerinde azalmalar tespit edilmiştir. Model deney sonuçları ile teorik sonuçların da birbirleri ile uyumlu oldukları belirlenmiştir.

Anahtar Kelimeler: Model deney, İlave düşey gerilme, Gerilme ölçer, Dikdörtgen temel, Merkez yükleme, Eksantrik yükleme

\section{Stress and Bearing Capacity Analyses under Rectangular Footing}

\begin{abstract}
In this study, the stress and the bearing capacity changes were experimentally and theoretically investigated in different loading conditions using rectangular model footing. The stress distribution was vertically obtained with the laboratory tests in central and eccentrically loading conditions using stress transducers. And also the load-settlement curves were obtained with load cell and displacement transducer. The test results were compared with theoretical results (Boussinesq, Westergaard and 2:1 Method). The loose sand was used during the tests. The model tests were conducted in the Geotechnical Laboratory of Civil Engineering Department of Iskenderun Technical University. The test results showed that the bearing capacity decreases with an increase in the load eccentricity. Also the stress values decrease while moving away from the center of the model footing. As seen that the model test results are compatible with the theoretical results each other.
\end{abstract}

Keywords: Model tests, Soil stress, Stress transducer, Rectangular footing, Central loading, Eccentrical loading

\footnotetext{
* Yazışmaların yapılacağı yazar: Yakup TÜREDİ, İskenderun Teknik Üniversitesi, Inşaat Fakültesi, Inşaat Mühendisliği Bölümü, Hatay, turediyakup@hotmail.com
} 


\section{GíRiş}

Zeminlerin kendi ağırlıkları ve uygulanan dış yükler, zemin içinde gerilmeler oluştururlar. Gerilme, uygulanan yükün şiddetine, yükün uygulandığ 1 alanın boyutlarına ve zemin özelliklerine bağlı olarak değişmektedir.

Zeminler, çok karmaşık bir malzeme olmaları nedeni ile zemin içerisinde gerçekçi gerilmedeformasyon analizleri yapmak oldukça zordur. Bu nedenle genellikle yaklaşık bir çözüm olan elastisite teorisi kullanılmaktadır.

Elastisite Teorisi kullanılırken şu kabuller yapılmaktadır.

1. Zemin elastik olup, gerilme-deformasyon ilişsisi doğrusaldır.

2. Zemin ortamı homojendir. Diğer bir deyişle, elastik sabitler, elastisite modülü $\mathrm{E}$ ve poisson oranı $\mu$ her noktada aynıdır.

3. Zemin ortamı izotroptur. Yani, özellikleri bir noktada, her yönde aynıdır.

4. Zemin ortamı yarı sonsuzdur. Yani, bir düzlemin altında, her yönde, sonsuz mesafeye uzanır [1].

Zemin yüzünde uygulanan bir yükten dolayı zemin kütlesi içindeki noktalarda gerilme artışları meydana geldiği bilinmektedir. Zemin yüzüne yakın bir yükten dolayı, alttaki zemin tabakalarına iletilen düşey gerilmelerin derinlikle dağılımı aşağıda gösterilmiştir (Şekil 1).

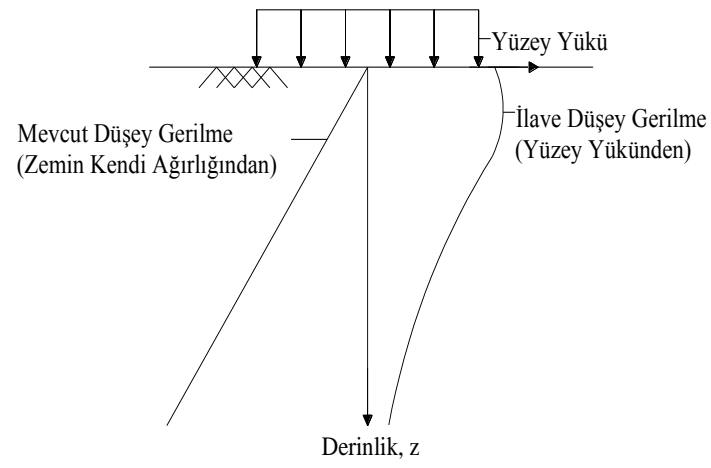

Şekil 1. Zeminde mevcut ve ilave düşey gerilmeler [1]
Rijit bir temel için kohezyonlu ve kohezyonsuz zeminlerde oluşan tepki gerilmeleri üniform olarak dağılmamaktadır. Q yükü ile yüklü bir A alanına sahip temelde rijit metoda göre zeminde oluşacak gerilme, Şekil 2'de görüldüğü gibi q=Q/A'dır.

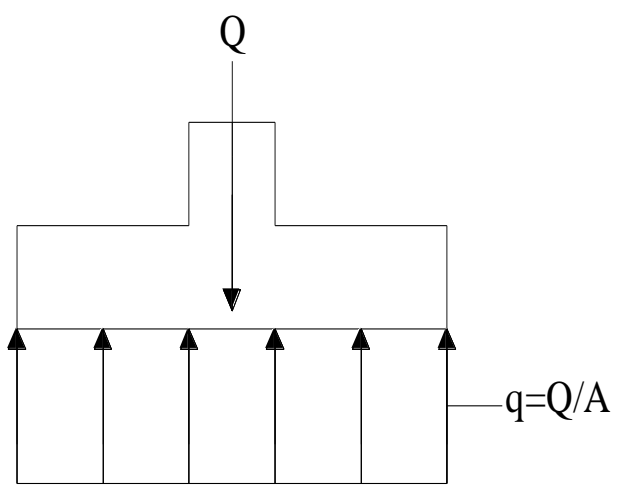

Şekil 2. Rijit kabule göre gerilme dağılımı [2]

Şekil 3'de görüldüğü üzere, iri daneli (kum, çakıl) zeminlere oturan eksantrik yüklü rijit temellerde, taban basıncı dağılımın ağırlık merkezi, eksantrik olarak etkiyen yükün altına doğru kaymaktadır $[3,4]$.

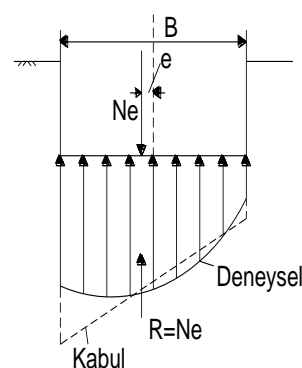

Küçük eksantrisite durumu

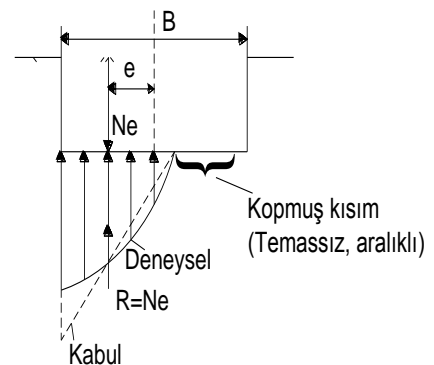

Büyük eksantrisite durumu
Şekil 3. Eksantrik yüklü temelde tipik basınç dağılımı

Bir yönde eksantrikliğe maruz bir dikdörtgen temelde, taban basıncı dağılımları geleneksel yönteme göre aşağıdaki gibi ifade edilmektedir (Şekil 4). 


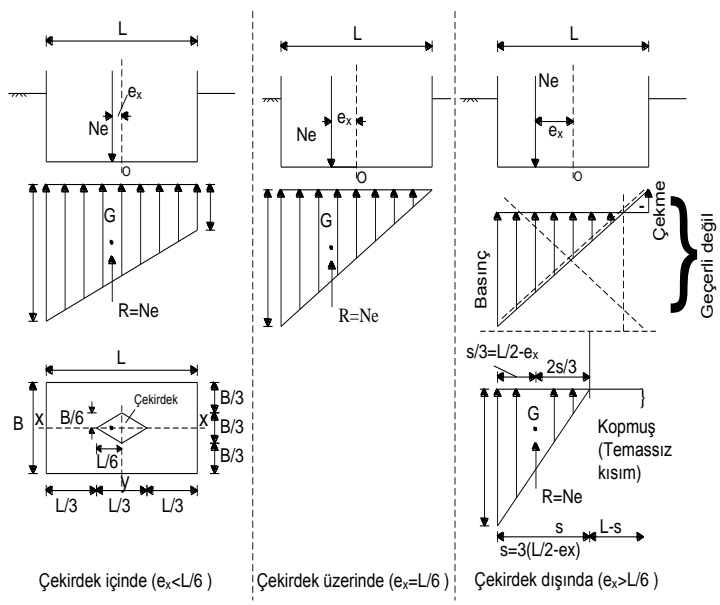

Şekil 4. Eksantrik yüklü bir dikdörtgen alan altında taban basıncı dağılımları

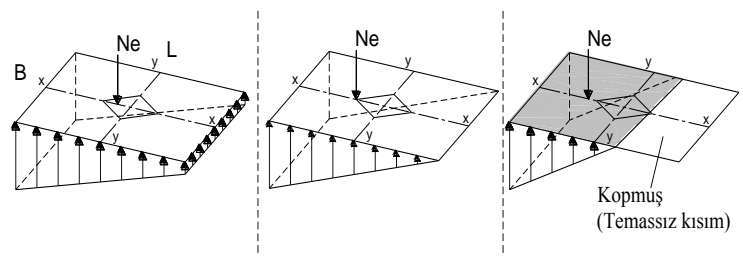

Şekil 5. Şekil 4'ün üç boyutlu görünüşleri

\section{Yük çekirdek çekirdek içinde $\left(\mathrm{e}_{\mathrm{x}}<\mathrm{L} / 6\right)$}

Taban basıncı dağılımının en büyük ve en küçük değerleri,

$$
\begin{aligned}
& \sigma_{\text {max } \min }=\frac{N_{e}}{A} \pm \frac{M_{y-y}}{W_{y-y}}=\frac{N_{e}}{B L} \pm \frac{N_{e} e_{x}}{\frac{B L^{2}}{6}} \\
& =\frac{N_{e}}{B L}\left(1 \pm \frac{6 e_{x}}{L}\right)
\end{aligned}
$$

2.Yük çekirdek sınırı üzerinde (özel durum, $\left.\underline{\mathrm{e}_{\mathrm{x}}}=\mathrm{L} / 6\right)$

$$
\sum Y=0, \frac{\sigma_{\max } L B}{2}=N_{e} \rightarrow \sigma_{\max }=\frac{2 N_{e}}{B L}
$$

Aynı bağıntı, Eşitlik 1'de $e_{x}=L / 6$ koyarak da elde edilebilmektedir.

3.Yük çekirdek dișında $\left(\mathrm{e}_{\mathrm{x}}>\mathrm{L} / 6\right)$ : Böyle bir durumda, temel tabanı ile zeminin teması, belli bir alanda kaybolmaktadır (kopmuş üçgen dağılım). Dağılımın en büyük değeri ise aşağıdaki eşitlikte verildiği gibidir.

$$
\begin{aligned}
& \sum Y=0, \frac{\sigma_{\max } s B}{2}=N_{e} \rightarrow \\
& \sigma_{\max }=\frac{2 N_{e}}{B L}=\frac{2 N_{e}}{3\left(\frac{L}{2}-e_{x}\right) B}=\frac{2 N_{e}}{3\left(L-2 e_{x}\right) B}
\end{aligned}
$$

Temel-zemin temasının kaybolduğu (gerilme almayan) kısmının uzunluğu ise Eşitlik 4'te ifade edilmektedir.

$$
L-s=L-3\left(L / 2-e_{x}\right)
$$

Zeminlerde meydana gelen düşey ve yatay gerilmelerin tahmini ve tespiti aynı zamanda da zeminlere oturan yüzeysel temellerde farkl1 yükleme koşulları için geliştirilmiş olan deney düzenekleri ve teknikleri mevcuttur. Gerilme ve farklı yükleme koşullarına ait birçok araştırmacı tarafından incelemeler yapılmıştır [5-16].

Terzaghi [5] tarafindan kum ve kil numunelerde düşey yüklerden dolayı oluşan yatay ve düşey gerilmeler, laboratuvar ortamında oluşturulan bir deney düzeneği ile ölçülmüştür.

Keskin [13] tarafindan kum zemin üzerine oturan yüzeysel temellerden oluşan ilave düşey gerilmeler incelenmiş ve uygulanan yük arttıç̧a ölçülen gerilme değerinin arttığ değerlerinin azaldığı ve yüzeye yakın yerlerde deney sonuçlarının teorik sonuçlara göre daha düşük değerler verdiği gözlenmiştir.

Bağrıaçık [15] tarafindan, kum zeminlere oturan farklı geometrilerdeki yüzeysel temellerde oluşan ilave düşey gerilme davranışları araştırılmıştır. 
Sonuç olarak; farklı geometrilerdeki temellerde şekil etkisinin önemli mertebelerde olduğu görülmüştür.

Örnek ve ark. (2014) [16] tarafindan kum zemine oturan eksantrik yüklü şerit temellerin analizi incelenmiştir ve yük eksantrisitesi arttıkça nihai taşıma gücünün azaldığı görülmüştür.

Boussinesq (1885) [17] tarafindan lineer, elastik, homojen, izotrop, yarı sonsuz ortamda, yüzeye etkiyen bir tekil yükten dolayı oluşan gerilme problemi çözülmüştür (Şekil 6).

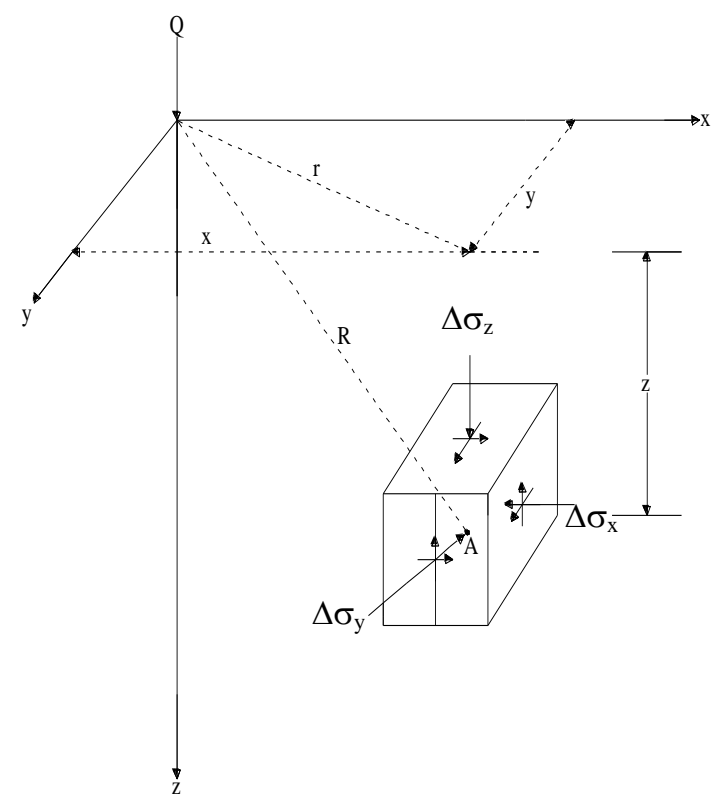

Şekil 6. Tekil yükten dolayı zemin içinde oluşan gerilmeler [18]

$Q$ tekil yükünden dolayı zemin içerisinde herhangi bir $\mathrm{z}$ derinliğinde oluşan gerilme değeri $\Delta \sigma_{\mathrm{z}}$ aşağıdaki gibidir.

$$
\Delta \sigma_{z}=\frac{Q}{z^{2}}\left\{\frac{3}{2 \pi} \frac{1}{[(r / z+1)]^{5 / 2}}\right\}
$$

Westergaard (1938) [19] tarafindan yatay şekil değiștirmelerin sıfır olduğu elastik bir ortamda, $Q$ yükünden dolayı, $z$ derinliğindeki bir $A$ noktasında oluşan (Şekil 7) düşey gerilme ifadesi aşağıdaki gibi önerilmiştir.

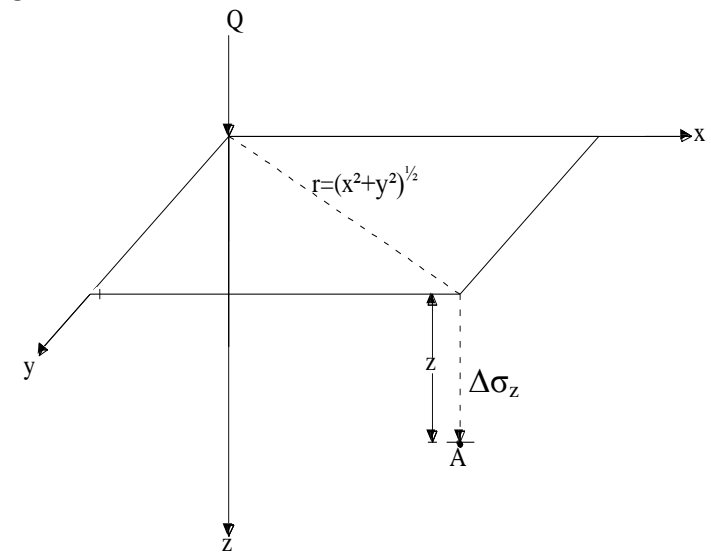

Şekil 7. Westergaard yaklaşımına göre tekil yükten dolayı oluşan düşey gerilme [18]

$$
\Delta \sigma_{z}=\frac{Q}{z^{2} \pi} \frac{1}{\left[1+2(r / z)^{2}\right]^{3 / 2}}
$$

Yüklenmiş bir alanın altında oluşan gerilme artışlarını yaklaşık olarak saptamak amacıyla, yüklemeden etkilenen bölgenin sınırlarını gösteren doğruların eğiminin 2 (düşey) / 1 (yatay) olduğu kabul edilmiştir. İkinci bir basitleştirici varsayım, herhangi bir $z$ derinliğindeki düşey gerilme dağılımının, bu düzlem boyunca üniform olacağıdır. Bu koşullar altında, $q$ yayılı yükü ile yüklü $B x L$ alanının $z$ derinliği altındaki düşey gerilme artışı aşağıdaki gibi ifade edilmektedir (Şekil 8).

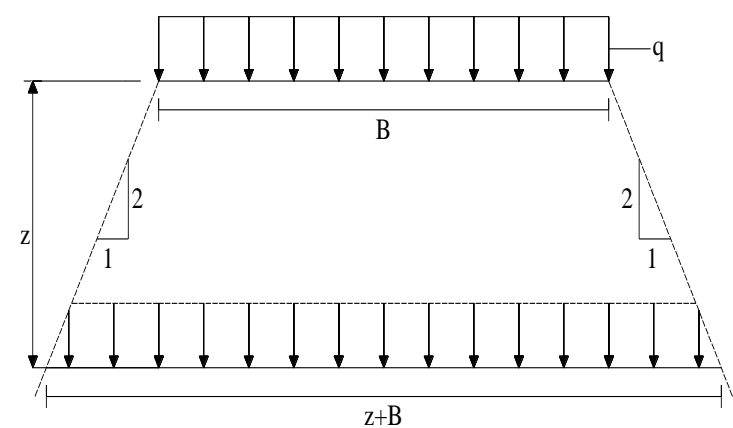

Şekil 8. Düşey gerilme artışları için basitleştirilmiş yaklaşım [20] 


$$
\Delta \sigma_{z}=\frac{q B L}{(B+z)(L+z)}
$$

$\mathrm{Bu}$ çalışmada, gevşek kum zemine oturan $10 \mathrm{~cm} \times 30 \mathrm{~cm}(\mathrm{BxL})$ dikdörtgen model temelin farklı yükleme koşullarında $(\mathrm{e} / \mathrm{L}=0$ ve $\mathrm{e} / \mathrm{L}=0,25)$ zeminde meydana getirdiği ilave düşey gerilme ve taşıma gücü davranışları deneysel ve teorik olarak araştırılmıştır. İlave düşey gerilme artışları 5 farklı derinlikte (1B, 2B, 3B, 4B, 5B) ve her bir derinlik için yatayda temelin merkezi $1.2 \mathrm{~B}, 2.4 \mathrm{~B}$ ve $3.6 \mathrm{~B}$ konumlarında gerime değerleri elde edilmiştir. Ayrıca yük-oturma değerleri de elde edilmiştir. Elde edilen sonuçlar, literatürde mevcut teorik yöntemlerle karşılaştırılmıştır. $10 \mathrm{~cm}$ x $30 \mathrm{~cm}$ boyutunda dikdörtgen temelin temellerin kullanıldı ̆̆ bu çalışmada toplam 10 adet model deney yapılmıştır.

\section{MATERYAL VE METOD}

Model deneyler, İskenderun Teknik Üniversitesi İnşaat Fakültesi İnşaat Mühendisliği Bölümü Geoteknik Laboratuvarı'nda yapılmıştır. Model deneyler, ebatları $125 \mathrm{~cm} \mathrm{x} 100 \mathrm{~cm}$ x $100 \mathrm{~cm}$ (uzunluk, genişlik, derinlik) olan dikdörtgen kesitli bir kasa içerisinde gerçekleştirilmiştir. Deney kasası iskeleti çelik profillerden olup, ön ve arka yüzü $10 \mathrm{~mm}$ kalınlığında cam, yan yüzeyler ile alt taban ise $3 \mathrm{~mm}$ kalınlığ imal edilmiştir.

Deneylerde kullanılan şerit temelin genişliği, (B), $0,1 \mathrm{~m}$ ve uzunluğu (L), 0,3 m'dir. Deneylerde kullanılan şerit temelin yükleme sistemi mekanizması Şekil 9'da, yükleme düzeneği ise Şekil 10'da yer almaktadır.

Çalışmalarda, Ceyhan nehir yatağından çıkarılan kum numuneler kullanılmıştır. Kullanılan kuma ait elek analizi, kesme kutusu, sıkılık, piknometre deney sonuçları Çizelge 1'de verilmiştir.

Uygulamalarda yüklemeler S-tipi yük ölçer (2000 kg kapasiteli) ve deplasmanlar ise LVDT deplasman ölçerler $(10 \mathrm{~cm}$ kapasiteli) ile ölçülmüştür.

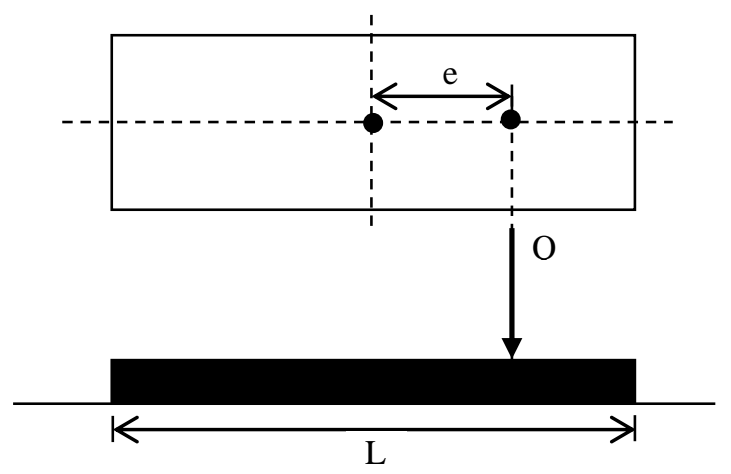

Şekil 9. Dikdörtgen temel ve yük eksantrisitesi

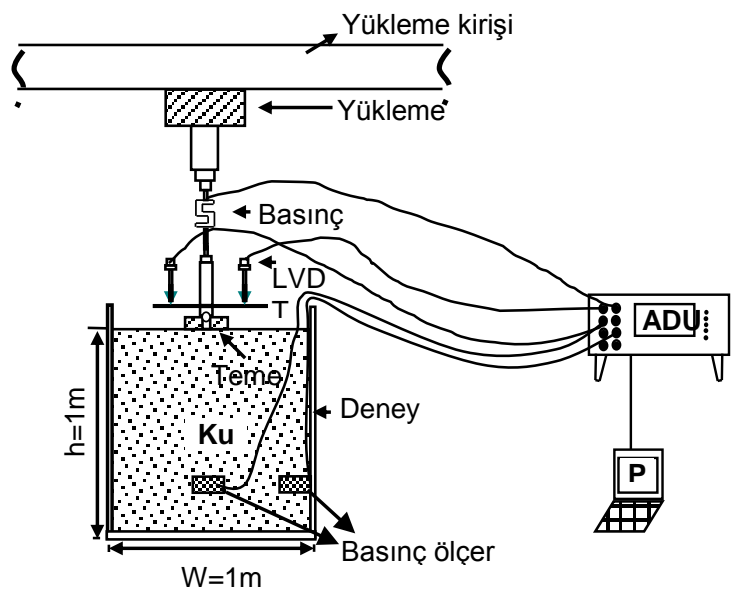

(a)

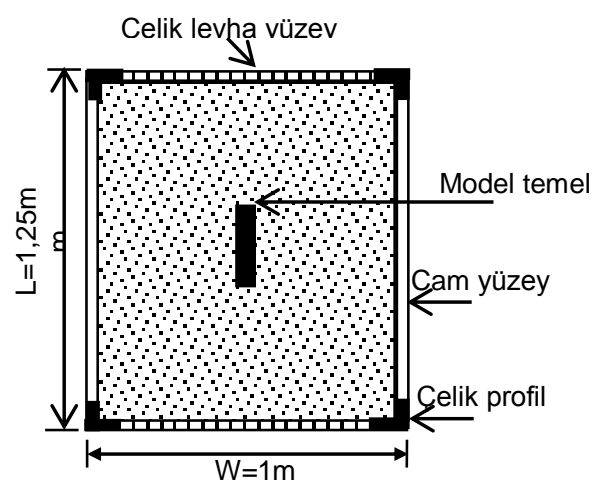

(b)

Şekil 10. Deneysel çalışmada kullanılan yükleme düzeneği $(a, b)$ 
Çizelge 1. Deney kumunun mühendislik özellikleri

\begin{tabular}{|c|c|}
\hline Özellik & Değer \\
\hline İri kum yüzdesi (\%) & 0,00 \\
\hline Orta kum yüzdesi (\%) & 65,00 \\
\hline İnce kum yüzdesi (\%) & 35,00 \\
\hline $\mathrm{D}_{10}(\mathrm{~mm})$ & 0,13 \\
\hline $\mathrm{D}_{30}(\mathrm{~mm})$ & 0,28 \\
\hline $\mathrm{D}_{60}(\mathrm{~mm})$ & 0,58 \\
\hline Üniformluk katsayısı, $\mathrm{C}_{\mathrm{u}}$ & 4,46 \\
\hline Derecelenme katsayısı, $\mathrm{C}_{\mathrm{c}}$ & 1,04 \\
\hline Özgül ağırlık & 2,72 \\
\hline $\begin{array}{l}\text { Maksimum kuru birim hacim ağırlık } \\
\left(\mathrm{kN} / \mathrm{m}^{3}\right)\end{array}$ & 17,11 \\
\hline $\begin{array}{l}\text { Minimum kuru birim hacim ağırlık } \\
\left(\mathrm{kN} / \mathrm{m}^{3}\right)\end{array}$ & 15,44 \\
\hline Kohezyon, c (kPa) & 0,00 \\
\hline İçsel sürtünme açısı, $\phi$ (derece) & 36,00 \\
\hline Zemin sinıfı (USCS) & SP \\
\hline
\end{tabular}

Zeminde meydana gelen düşey gerilmeleri ölçmek amacıyla $2000 \mathrm{~kg}$ kapasiteli gerilme ölçer kullanılmıştır (Şekil 11).

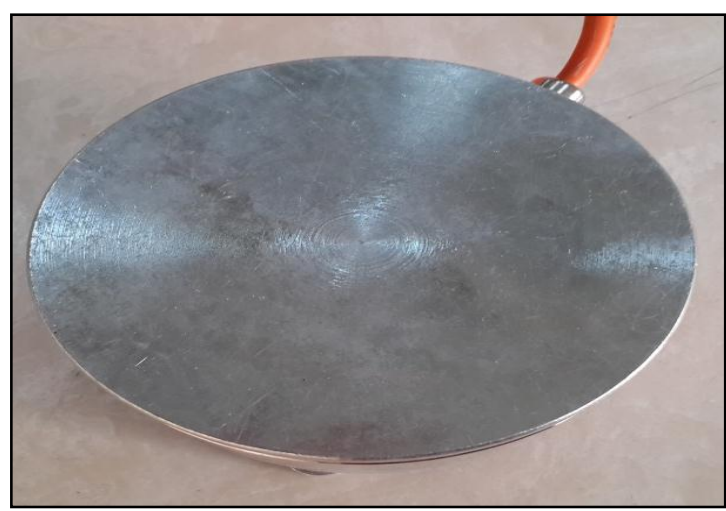

Şekil 11. Gerilme ölçer

Deneylerde takip edilen yöntem aşağıda verilmiştir.

- Deney kasasının içine yerleştirilen kumun yüzeyi su terazisi ile kontrol edildikten sonra gerilme ölçer ölçüm alınmak istenen seviyelere yerleştirilmiştir.
- Daha sonra, gevşek durum için $\gamma \mathrm{k}=17,11 \mathrm{kN} / \mathrm{m}^{3}$ olacak şekilde kasa içerisine tabakalar halinde kum zemin yerleştirilmiştir.

- Düzeltilen kum zemin üzerine model temel plakası aynı şekilde teraziye alınarak düzgün bir şekilde yerleştirilmiştir (Şekil 12).

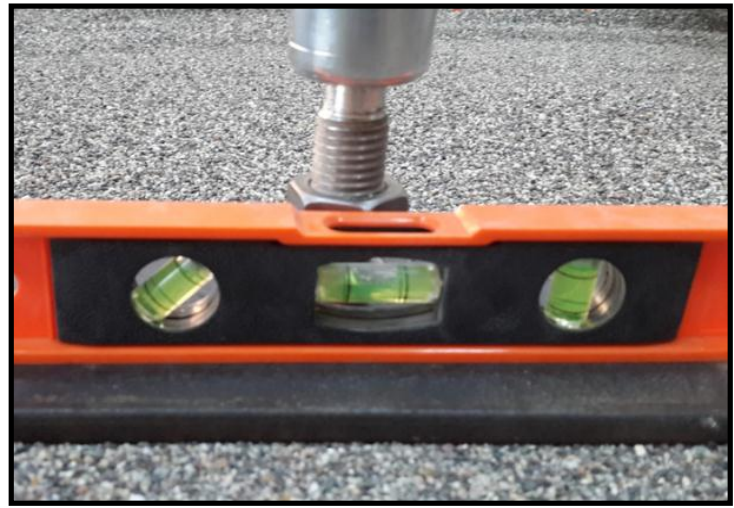

Şekil 12. Model temel plakasının yerleştirilmesi

- Deney sırasında, kademeli olarak yüklemeye devam edilmiş ve yükleme hızı her kademede sabit tutulmuştur.

- Her yükleme kademesinde oluşan gerilmeler, 16 kanal girişli ADU (Autonomous Data Unit) veri işleme cihazından okunarak sayısal hale dönüştürülmüştür. Veri işleme ünitesinden bilgisayara aktarılan değerler Geotechnical Software Ds7 yazılımı kullanılarak işlenmiştir. Daha sonra da okumalar bilgisayarda Excel programiyla düzenlenerek grafik olarak sunulmuştur.

\section{BULGULAR VE TARTIŞMA}

Çalışmada, gevşek kum zemine oturan $\mathrm{B}=10 \mathrm{~cm}$ ve $\mathrm{L}=30 \mathrm{~cm}$ ile kalınlığ $18 \mathrm{~mm}$ olan rijit çelik plaka model temel beş farklı derinlik (1B, 2B, 3B, 4B ve 5B) için ilave düşey gerilme değerleri ile yükoturma ilişkileri iki farklı yük eksantrisitesinde incelenmiştir. Her bir derinlik için yatay doğrultularda (temelin merkezi ile temelin merkezinden 1,2B, 2,4B, ve 3,6B uzaklıktaki konumlarında yerleştirilen) gerilme değerleri elde edilmiştir. 
İki farklı yükleme $(\mathrm{e} / \mathrm{L}=0, \mathrm{e} / \mathrm{L}=0,25)$ koşulunda yükleme düzenekleri ve yük-oturma eğrileri aşağıdaki şekillerde verilmiştir (Şekil 13-14).

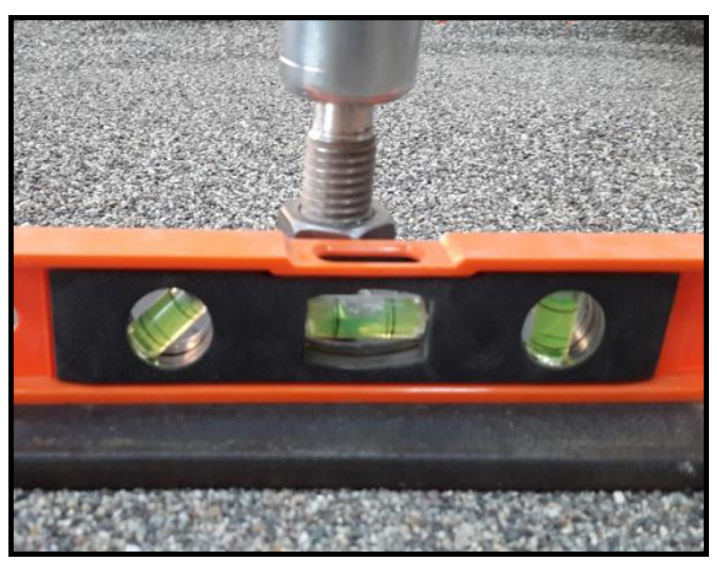

a) Merkez yükleme $(\mathrm{e} / \mathrm{L}=0)$

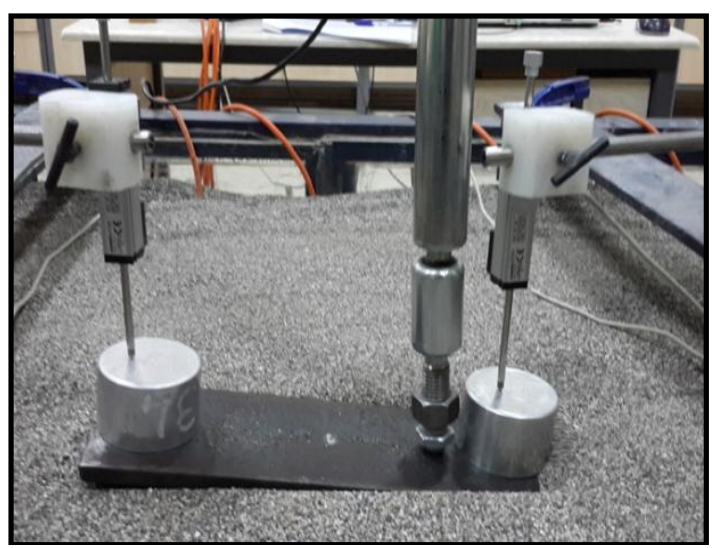

b) eksantrik yükleme $(\mathrm{e} / \mathrm{L}=0,25)$

Şekil 13. Merkezi (a) ve eksantrik (b) yükleme

Grafik sonuçlarından, en büyük yük değerinin $\mathrm{e} / \mathrm{L}=0$ (merkez yükleme) durumunda elde edildiği görülmüştür. Eksantrisite arttıkça yük değeri azalmıştır. Örneğin, merkez yükleme $(\mathrm{e} / \mathrm{L}=0)$ durumunda $\mathrm{e} / \mathrm{L}=0,25$ yükleme durumuna göre 2 kata varan bir artış gözlenmiştir.

Beş farklı derinlikte (1B, 2B, 3B, 4B ve 5B) elde edilen düşey gerilme artışı değerleri; Boussinesq [17], Westergaard [19], üniform yayılı yük

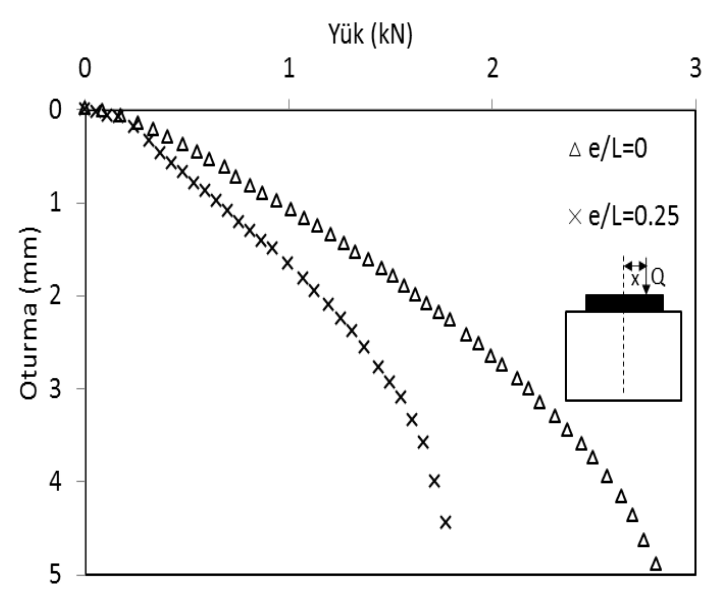

Şekil 14. Yük-oturma ilişkisi

(Boussinesq) ve basit kabul çözümleriyle karşılaştırılmıştır. Temelin merkezinde yer alan gerilme ölçer tarafından $\mathrm{e} / \mathrm{L}=0$ yüklemesi için farklı derinliklerde okunan düşey gerilme değişimleri grafik halinde Şekil 15'de sunulmuştur.

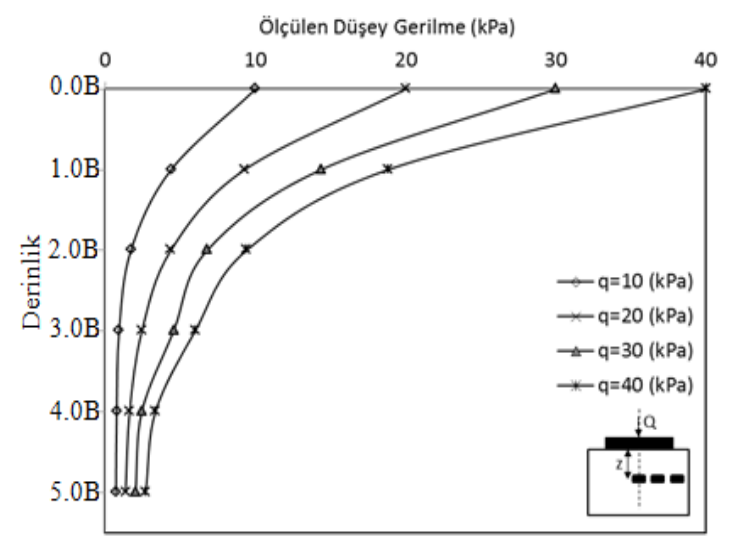

Şekil 15. e/L=0 yükleme durumunda farklı derinliklerde ve yük değerlerinde oluşan düşey gerilmeler

$\mathrm{e} / \mathrm{B}=0$ yükleme durumunda, uygulanan farklı yük $(\mathrm{q}=10 \mathrm{kPa}, \mathrm{q}=20 \mathrm{kPa}, \mathrm{q}=30 \mathrm{kPa}, \mathrm{q}=40 \mathrm{kPa})$ değerlerinde derinlik boyunca düşey gerilme değerlerinin azaldığı görülmektedir. Temel yüzeyinden 1,0B derinlikte meydana gelen düşey gerilme değerlerinde, temel yüzeyine göre yaklaşık 
\%40, 5B için ise yaklaşık \%90 oranlarına varan azalmalar görülmektedir.

Eksantrik yükleme durumunda uygulanan düşey gerilme değerleri hesaplanırken, eksantrik yüklü temeller altında oluşan basınç dağılımındaki formülasyondan elde edilen $\sigma_{\max }$ değeri kullanılmıştır (Şekil 16). e/L=0,25 yüklemesi için merkezin altında ölçülen düşey gerilme değişimleri Şekil 17'de sunulmuştur.

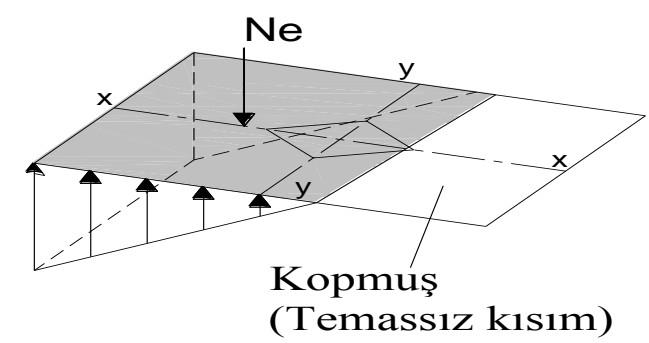

Şekil 16. Yük çekirdek dişında iken oluşan taban basınç dağılımı

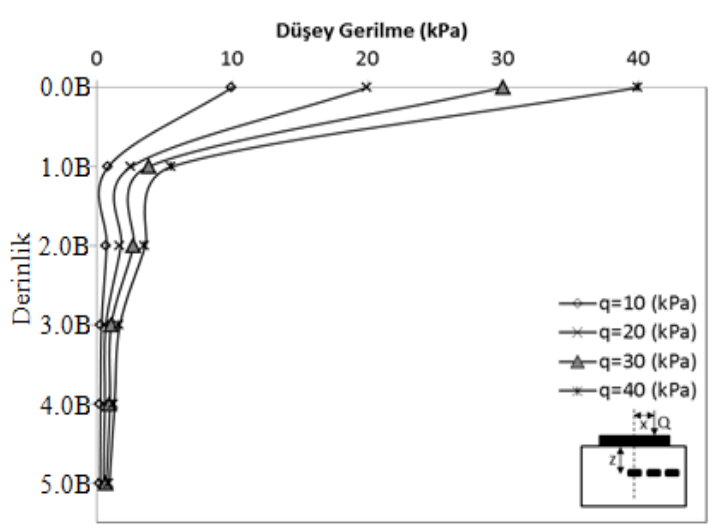

Şekil 17. e/L=0,25 yükleme durumunda farklı derinliklerde ve yük değerlerinde oluşan düşey gerilmeler (merkez gerilme ölçer)

$\mathrm{e} / \mathrm{B}=0,25$ yükleme durumunda ise temel yüzeyinden $1,0 \mathrm{~B}(0,1 \mathrm{~m})$ derinlikte meydana gelen düşey gerilme değerlerinde temel yüzeyine göre yaklaşık \%90, $0,5 \mathrm{~m}$ için ise yaklaşı $\% 98$ oranlarına varan azalmalar görülmektedir.

$10 \mathrm{kPa}, 20 \mathrm{kPa}, 30 \mathrm{kPa}$ ve $40 \mathrm{kPa}$ yüzeyde oluşan ilave düşey gerilmelere karşılık beş farklı derinlikte okunan ilave düşey gerilme değerleri teorik sonuçlarla birlikte grafik halinde toplu olarak sunulup karşılaştırılmıştır (Şekil 18-21). Ayrıca $30 \mathrm{kPa}$ merkezi yükleme altında uygulanan düşey gerilme değeri için deney ve teorik yöntemlerden elde edilen sonuçlar, Çizelge 2'de yer almaktadır.

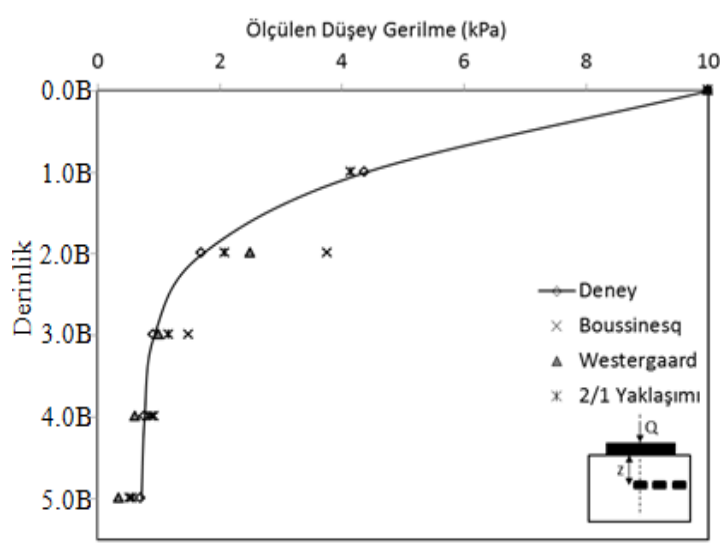

Şekil 18. e/L=0 yükleme durumunda $10 \mathrm{kPa}$ için farklı derinliklerde oluşan düşey gerilmelerin teori ile karşılaştırılması

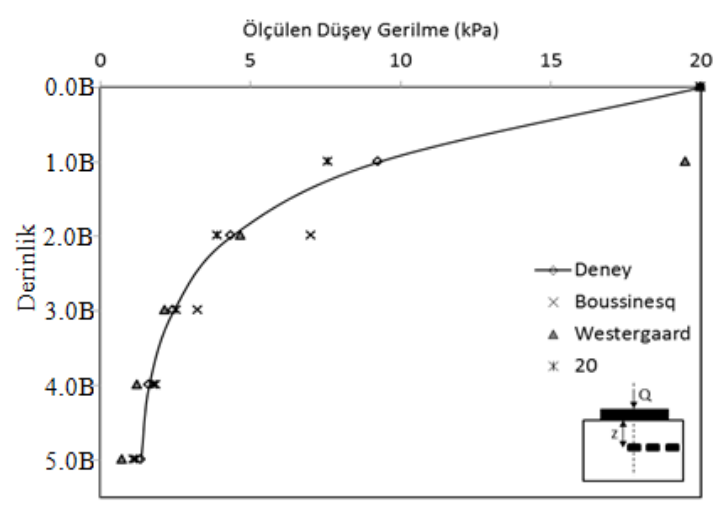

Şekil 19. e/L=0 yükleme durumunda $20 \mathrm{kPa}$ için farklı derinliklerde oluşan düşey gerilmelerin teori ile karşılaştırılması 


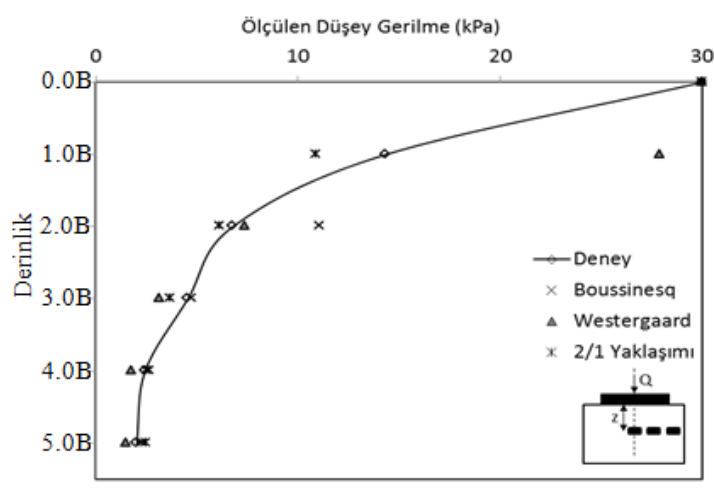

Şekil 20. e $/ \mathrm{L}=0$ yükleme durumunda $30 \mathrm{kPa}$ için farklı derinliklerde oluşan düşey gerilmelerin teori ile karşılaştırılması

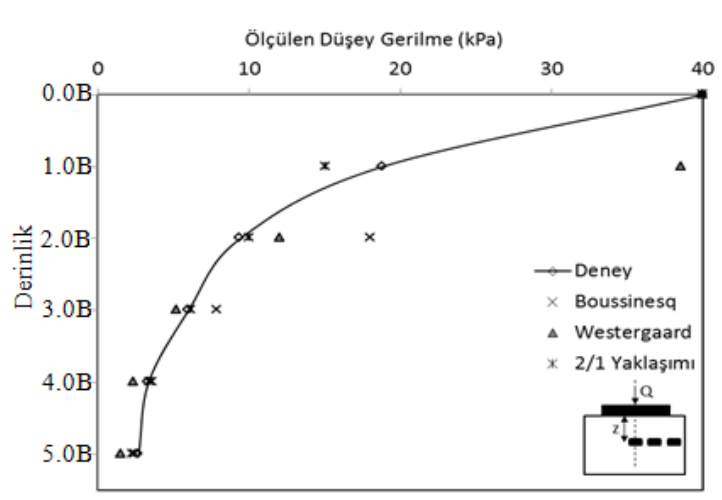

Şekil 21. e $/ \mathrm{L}=0$ yükleme durumunda $40 \mathrm{kPa}$ için farklı derinliklerde oluşan düşey gerilmelerin teori ile karşılaştırılması

Boussinesq ve Westergaard yaklaşımlarına ait gerilme değerlerinin yüzeye yakın kısımlarda çok yüksek ve deney sonuçlarından oldukça farklı oldukları görülmektedir. Gerilme değerleri derinlik arttıkça azalmakta ve Boussinesq, Westergaard, 2/1 yaklaşımı çözümlerinin deney sonuçlarına oldukça yakın oldukları görülmektedir. Sadece yüzeye yakın kısımlarda Boussinesq yaklaşımında farklılıklar olduğu belirlenmiştir. Literatür incelendiğinde bu tür problemlerin çözümünde yüzeye yakın noktalardaki gerilmelerin bu iki hesap yöntemine göre farklılıklar gösterdiği ve
Çizelge 2. $30 \mathrm{kPa}$ uygulanan düşey gerilme için deney ve teorik sonuçlar

\begin{tabular}{|c|c|c|c|}
\hline Yöntem & Derinlik & $\begin{array}{l}\text { Uygulanan } \\
\text { Düşsey } \\
\text { Gerilme (kPa) }\end{array}$ & $\begin{array}{l}\text { Ölçülen } \\
\text { Düşey } \\
\text { Gerilme } \\
\text { (kPa) }\end{array}$ \\
\hline \multirow{5}{*}{ Deney } & $1,0 \mathrm{~B}$ & 30 & 14,346 \\
\hline & $2,0 \mathrm{~B}$ & 30 & 6,776 \\
\hline & $3,0 \mathrm{~B}$ & 30 & 4,551 \\
\hline & $4,0 \mathrm{~B}$ & 30 & 2,435 \\
\hline & $5,0 \mathrm{~B}$ & 30 & 2,017 \\
\hline \multirow{5}{*}{ Boussinesq } & $1,0 \mathrm{~B}$ & 30 & 41,912 \\
\hline & $2,0 \mathrm{~B}$ & 30 & 11,076 \\
\hline & $3,0 \mathrm{~B}$ & 30 & 4,755 \\
\hline & $4,0 \mathrm{~B}$ & 30 & 2,675 \\
\hline & $5,0 \mathrm{~B}$ & 30 & 2,304 \\
\hline \multirow{5}{*}{ Westergaard } & $1,0 \mathrm{~B}$ & 30 & 27,941 \\
\hline & $2,0 \mathrm{~B}$ & 30 & 7,384 \\
\hline & $3,0 \mathrm{~B}$ & 30 & 3,170 \\
\hline & $4,0 \mathrm{~B}$ & 30 & 1,783 \\
\hline & $5,0 \mathrm{~B}$ & 30 & 1,536 \\
\hline \multirow{5}{*}{$\begin{array}{l}\text { Üniform } \\
\text { yayılı yük } \\
(2: 1 \\
\text { dağılımı) }\end{array}$} & $1,0 \mathrm{~B}$ & 30 & 10,914 \\
\hline & $2,0 \mathrm{~B}$ & 30 & 6,200 \\
\hline & $3,0 \mathrm{~B}$ & 30 & 3,715 \\
\hline & $4,0 \mathrm{~B}$ & 30 & 2,547 \\
\hline & $5,0 \mathrm{~B}$ & 30 & 2,500 \\
\hline
\end{tabular}

buna karşılık derinlik arttıkça değerlerin birbirine yaklaştığı görülmektedir [21]. Derinlere inildikçe sonuçların birbirine yakın değerler verdiği görülmektedir. 5,0B derinlikte $30 \mathrm{kPa}$ uygulanan düşey gerilme değeri için deney, Boussinesq yaklaşımı, Westergaard yaklaşımı, Üniform Yayılı Yük (2:1 dağılımı) yaklaşımı ile ölçülen düşey gerilme değerleri sırasıyla 2,017 $\mathrm{kPa}, 2,304 \mathrm{kPa}$, $1,536 \mathrm{kPa}$ ve $2,500 \mathrm{kPa}$ değerleri olmuştur.

Şekil 22'de $10 \mathrm{~cm}$ x $30 \mathrm{~cm}$ dikdörtgen temelin merkezi yükleme $(\mathrm{e} / \mathrm{L}=0)$ durumunda derinlik boyunca $(1,0 \mathrm{~B}, 2,0 \mathrm{~B}, 3,0 \mathrm{~B}, 4,0 \mathrm{~B}$ ve $5,0 \mathrm{~B})$ oluşan yatay noktalardaki gerilme değerleri yüzeyde uygulanan $30 \mathrm{kPa}$ yükleme durumu için grafik halinde verilmiştir. 


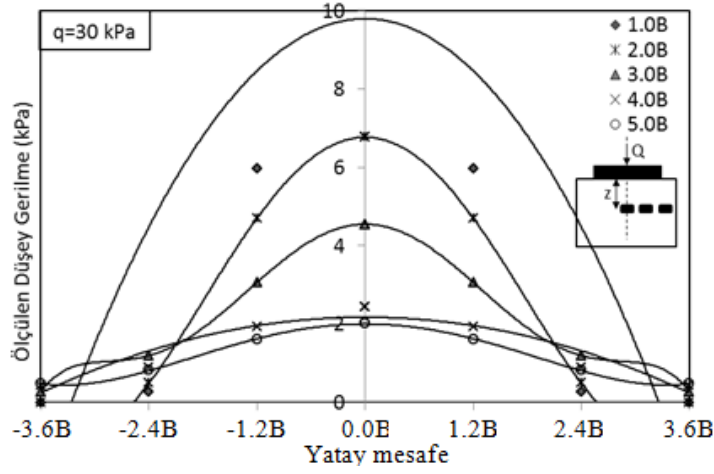

Sekil 22. e $/ \mathrm{L}=0$ yükleme durumunda 5 farkl derinlikte, yatayda oluşan düşey gerilme değerlerinin karşılaştırılması

Şekilden, yüzeyde $30 \mathrm{kPa}$ uygulanan düşey yüke bağlı olarak oluşan gerilme değerlerinin her bir derinlik için yükün uygulandığı noktanın altında olan gerilme ölçerden maksimum değerler verdiği ve temel merkezinden uzaklaştıkça bu değerlerin azaldığ 1 görülmektedir. Örneğin, 3B derinlikte temel merkezinden $1,2 \mathrm{~B}, 2,4 \mathrm{~B}$ ve $3,6 \mathrm{~B}$ yatay mesafede meydana gelen düşey gerilmeler incelendiğinde, temel merkezine göre yaklaşık olarak gerilme değerlerinde sırasıyla $\% 35, \% 74$ ve $\% 94$ oranlarında azalmalar meydana geldiği görülmektedir. Kenar noktalarda $(2,4 \mathrm{~B}=0,24 \mathrm{~m})$ ve $3,6 \mathrm{~B}(0,36 \mathrm{~m}=$ yatay noktalar $)$ noktalarında daha az okuma alınmasının sebebi, temel boyutu ve yükün uygulandığı noktanın gerilme ölçere uzak olmasıdır. Eksantrik yükleme $(\mathrm{e} / \mathrm{L}=0,25)$ durumunda yatay noktalardaki gerilme değerleri yüzeyde uygulanan $30 \mathrm{kPa}$ yükleme durumu için sonuçlar Şekil 23 ’te grafik halinde verilmiştir.

Uygulanan düşey yüke bağlı olarak oluşan gerilme değerlerinin her bir derinlik için yükün uygulandığı noktaya en yakın olan yatayda $1,2 \mathrm{~B}$ $(0,12 \mathrm{~m})$ noktasında diğer noktalara göre daha fazla olduğu görülmektedir. 3B derinlik için 1,2B noktasında elde edilen gerilme değerlerinin, temelin tam merkezine yerleştirilen gerilme ölçerden elde edilen değerlerine göre $\% 42$ oranında bir artış gösterdiği belirlenmiştir. Elde edilen sonuçlar aşağıda maddeler halinde sunulmuştur.

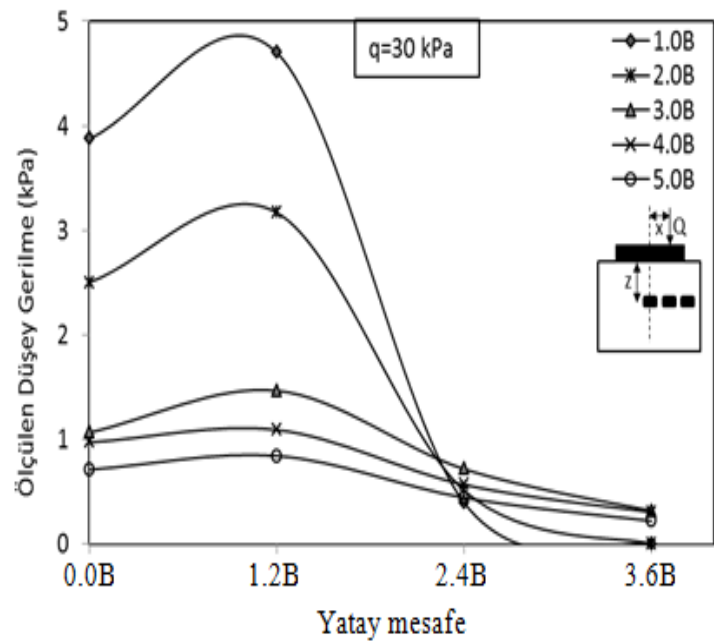

Şekil 23. e/L=0,25 yükleme durumunda 5 farklı derinlikte, yatayda oluşan düşey gerilme değerlerinin karşılaştırılması

\section{SONUÇLAR}

$\mathrm{Bu}$ çalışmada, gevşek kum zemine oturan $10 \mathrm{~cm} \times 30 \mathrm{~cm}$ dikdörtgen kesitli model temelin farklı yükleme koşullarında yük-oturma ilişkileri ve zeminde meydana getirdiği ilave düsşey gerilme davranışları deneysel ve teorik olarak araştırlmış̧ır.

Eksantrisite arttıkça taşıma gücü değerleri azalmıştır. Merkez ve eksantrik yükleme durumlarında derinliğe bağlı olarak düşey gerilme değerlerinde azalmalar görülmüştür. Eksantrik yükleme durumunda yükün uygulandığı noktaya yakın olan gerilme ölçerden okunan gerilme değeri daha fazla olmuştur. Boussinesq ve Westergaard yaklaşımlarına göre yüzeysel kısımlarda deneysel sonuçlar çok daha küçük sonuçlar vermiştir. Basit yaklaşım (2/1 Yöntemi) yaklaşımı ve diğer yöntemlerde de derinliklere inildikçe deney sonuçlarıyla daha yakın sonuçlar elde edildiği gözlenmiştir. Örneğin $5 \mathrm{~B}$ derinlikte deney, Boussinesq, Westergaard ve 2:1 dağılımı için sırasıyla yaklaşık olarak $2,017 \mathrm{kPa}$, 2,304 $\mathrm{kPa}, 1,536 \mathrm{kPa}$ ve 2,500 $\mathrm{kPa}$ olarak ölçülmüştür. 


\section{TEŞEKKÜR}

Bu çalışma; Mustafa Kemal Üniversitesi Bilimsel Araştırma Projeleri (BAP) Koordinasyon Birimi tarafından desteklenmiştir (Proje No: 11881).

\section{KAYNAKLAR}

1. Uzuner, B.A., 1998. Çözümlü Problemlerle Temel Zemin Mekaniği, Teknik Yayınevi, Ankara, 376s.

2. Kanıt, R., 2003. Temel İnşaatı, GAZİ Kitabevi Tic. Ltd. Şti., Ankara, 102-105.

3. Uzuner, B. A., 1975. Centrally and Eccentrically Loaded Strip Foundations on Sand, Doktora Tezi, University of Strathclyde, Glasgow, UK.

4. Uzuner, B. A., 2012. Çözümlü Problemlerle Temel Zemin Mekaniğ, Derya Yayınevi, Trabzon, 397s-400s.

5. Terzaghi, K., 1920. Old Earth Pressure Theories and New Test Results. Engrg", News-Rec., 85 (14), 632-637.

6. Donath, A. D., 1891. Untersuchungen Veber den Erddruck auf Stuetzwaende, Zeitschrift fuer Bauwesen, Berlin, Germany.

7. Scheidig, K.,, 1926. Die Verteilung Senkrechter Drücke in Schüttungen, Dissertation, Freiberg,

8. Kjellman, W., 1936. Report on an Apparatus for the Determination of the Coefficient of Lateral Earth Pressure at Rest", Proc. 1st Int. Conf. on Soil Mech. and Fnd. Engrg., Harvard Printing Office, Cambridge, Mass., 2, 16-20.

9. Hendron, A.J., 1963. The Behaviour of Sand in One Dimensional Compression, Ph.D. Thesis, University of Illinios, USA.

10. Sağlamer, A., 1972. Kohezyonsuz Zeminlerde Sükunetteki Toprak Basıncı Katsayısının Zemin Parametreleri Cinsinden İfadesi, Doktora Tezi, İstanbul Teknik Üniversitesi, Fen Bilimleri Enstitüsü, İstanbul.

11. Uzuner, B. A., Bektaş, F., Moroğlu, .B., 2000. Kumda Merkezi ve Eksantrik Yüklü Şerit Temellerde Taban Gerilmelerinin Dağılışları, Zemin Mekaniği ve Temel Mühendisliği Sekizinci Ulusal Kongresi, İstanbul Teknik Üniversitesi, 32s-38s., İstanbul.
12. Moroğlu, B., Uzuner B. A., 2002. Donatıl1 Kuma Oturan Eksantrik Yüklü Model Yüzey Şerit Temelinin Davranışı, Zemin Mekaniği ve Temel Mühendisliği Dokuzuncu Kongresi, Anadolu Üniversitesi, 277-287s., Eskişehir.

13. Keskin, M. S., 2004. Zeminlerde Oluşan İlave Düşey Gerilmelerin Değişik Yöntemlerle İrdelenmesi, Yüksek Lisans Tezi, Çukurova Üniversitesi, Fen Bilimleri Enstitüsü, Adana.

14. Saran, S., Kumar, S., Garg, K. G., Kumar, A., 2007. Analysis of Square and Rectangular Footings Subjected to Eccentric-Inclined Load Resting on Reinforced Sand, Journal of Geotechnical and Geoenvironmental Engineering, 25:123-137.

15. Bağrıaçık, B., 2010. Zeminlerdeki Gerilme Durumlarının Deneysel ve Teorik Olarak İncelenmesi, Yüksek Lisans Tezi, Çukurova Üniversitesi Fen Bilimleri Enstitüsü, Adana.

16. Örnek M., Türedi Y., Dal, K., 2014. Kum Zemine Oturan Eksantrik Yüklü Şerit Temellerin Analizi, Zemin Mekaniği ve Temel Mühendisliği 2. Özel Konulu Sempozyumu, 24-25 Nisan 2014, Antalya.

17. Boussinesq, J., 1885. Application des Potentiels a L'etude de L'equilbre et du Movement des Solids Elastiques, GauthierVillars, Paris.

18. Das, B. M., 2001. Principles of Geotechnical Engineering", Brooks Cole, USA.

19. Westergaard, H. M., 1938. A Problem of Elasticity Suggested by a Problem in Soil Mechanics, Soft Material Reinforced by Numerous Strong Horizontal Sheets, Contributions to the Mechanics of Solids, S. Timoshenko 60th Anniversary Volume, Newyork-Mac Millan.

20. Özaydın, K., 1989. Zemin Mekaniği, MEYA Matbaacılık ve Yayıncılık, İstanbul, 395s.

21. Özaydın, K., 2011. Zemin Mekaniği, Birsen Yayınevi, 140-146s., İstanbul. 